\title{
Natural co-infection and species composition of Eimeria in sheep in Al-Baha area, Saudi Arabia
}

\author{
Mohamed Moussa Ibrahim ${ }^{1,2}$ and Amro Al Sayed Afsa ${ }^{3}$ \\ 1- Zoology Department, Faculty of Science, Suez Canal University, Ismailia, Egypt. \\ 2- Science Department, Faculty of Education, Al-Baha University, Al-Baha, Saudi Arabia. \\ 3- Al-Baha Official abattoirs, Al-Baha, Saudi Arabia
}

E-mail: $\underline{\text { m_mossa77@hotmail.com and mmossa77@gmail.com }}$

\begin{abstract}
This work aimed to 1) identify Eimeria species of sheep 2) investigates the factors that might potentially influence their prevalence and parasite load and 3) study the associations between Eimeria species. This study was conducted in Al-Baha area, Saudi Arabia from March 2012 to May 2013. Out of 487 faecal samples examined, $227(46.61 \%)$ were positive for Eimeria oocysts. The species composition of Eimeria consisted of eight species. They were E. crandallis (29.8\%), E. bakuensis (27.9\%), E. weybridgensis (23.4\%), E. ahsata (12.3\%), E. intricate (9.9\%), E. faurei (7.6\%), E. parva $(4.7 \%)$ and E. pallida $(2.9 \%)$. The overall mean species richness of Eimeria species harbored per host was $1.27 \pm 0.07$. Host age, season and location played a significant role in determining Eimeria species richness, prevalence and parasite load. Significant negative correlations were found between host age and both prevalence and oocysts' number per gram of faeces (OPG). Multiple-species infections were commonly present in all age categories and declined with host age. Some Eimeria species consistently co-occurred and positive pair-wise associations were found. In conclusion, the prevalence and parasite load are affected by host age and season.
\end{abstract}

Keywords: Eimeria, oocysts, sheep, co-infection, host age, season, Saudi Arabia.

\section{INTRODUCTION}

Coccidiosis is a worldwide distributed disease and one of the most economically important infections that threating sheep production. Coccidia infect the intestinal tract with clinical manifestations that vary from asymptomatic to severe diarrhea with blood and gut lining tissue in the feces. Subclinical coccidiosis is the most common form of the disease. Subclinical coccidiosis cannot be readily identified, therefore has a significant impact on the flock's health and production efficiency (Wang et al., 2010; Cavalcante et al., 2012).

Co-infection by multiple parasite species is the normal state of animals (Griffiths et al., 2011; Viney \& Graham, 2013). Co-infection refers to a situation in which individuals harbour two or more infections simultaneously; this differs from monoinfection in which individuals harbour only one infection (Raso et al., 2007). Coinfection has important ecological (Graham, 2008; Brooker \& Clements, 2009), epidemiological and clinical consequences (Pullan \& Brooker, 2008; Brooker \& Clements, 2009). The distribution of co-infection is not only pervasive, but also heterogeneous. The heterogeneity is common among villages and among individual hosts in the number and diversity of infections borne (Foreyt, 1990; Viney \& Graham, 2013). The co-infection is common with Eimeria species in sheep. There is evidence 
for interactions between parasite species, highlighting the importance of understanding these relationships before devising control strategies against specific species in livestock systems (Lello et al., 2004; Craig et al., 2007). In assessment of the dynamics of co-infections (either naturally, or following external perturbation), measures of abundance will be more sensitive than prevalence. Furthermore, abundance will often be more informative for studies of infracommunity dynamics (Viney \& Graham, 2013).

Fifteen Eimeria species have been documented from the sheep (Platzer et al., 2005; Wang et al., 2010). In Saudi Arabia, elven Eimeria species have been found in sheep, namely E. bakuensis (formally, E. ovina), E.weybridgensis, E. parva, E. faurei, E. crandallis, E. ninakohlyakimovae, E. ahsata, E. granulosa, E. intricate, E. pallida and E. arloingi (Kasim \& Al-Shawa, 1985; Toulah, 2007).

Few studies already have been carried out on total oocyst excretion of eimerians in different seasons in different age classes of sheep in Saudi Arabia (Toulah, 2007). The species composition and the importance of each species of Eimeria in Al-Baha area are unknown. Therefore, it was of interest to evaluate their prevalence and abundance in sheep. In addition to, study the interaction between Eimeria species.

\section{MATERIALS AND METHODS}

\section{The study area}

The study was conducted in Al-Baha area, west-south Saudi Arabia $\left(20^{\circ} \mathrm{N}, 41^{\circ}\right.$ - 42 ${ }^{\circ}$ E) from March 2012 to May 2013. The study area is mainly hilly, with small areas of either mountainous or flat land and extends from 500 to $2500 \mathrm{~m}$ a.s.l. The climate in Al-Baha has two extremes. Mild winters and hot summers, with an average annual rainfall between 100 and $250 \mathrm{~mm}$, prevail in the lowlands; cold winters and mild summers, with an average annual rainfall between 229 and $581 \mathrm{~mm}$, prevail in the highlands (Ibrahim et al., 2008).

\section{Sample collection}

A total of 487 sheep from three localities in Al-Baha area were chosen randomly from farms. There were no prophylactic treatments against coccidiosis. Faecal samples of approximately 3-5 g were collected directly from the rectum using examination gloves. All samples were placed into plastic bags and were classified into three age categories: young ( $<6$-months old), immature (6-12-months old) and adult (>12-months old) and two seasons (dry: September -January and wet season: February-July). The animals' ages were estimated by examining their teeth and asking the animals' owner. The structure of the sampled host population of sheep according to season, locality, host sex and age categories was shown in Table (1). The collected samples were stored at $4^{\circ} \mathrm{C}$ until being examined.

Table 1: The structure of the sampled host population of sheep.

\begin{tabular}{lcc}
\hline Factors considered & & No. of sheep examined \\
\hline \multirow{2}{*}{ Season } & Dry season & 239 \\
& Wet season & 248 \\
\hline \multirow{2}{*}{ Location } & Al-Baha & 165 \\
& Al-Aqiq & 176 \\
\hline \multirow{2}{*}{ Sex } & Al-Mikhwah & 146 \\
\hline \multirow{2}{*}{ Age categories } & Male & 260 \\
& Female & 227 \\
\hline Total & Young (<6 months old $)$ & 166 \\
& Immature $(6-12$ months old $)$ & 170 \\
& Adult $(>12$ months old $)$ & 151 \\
\hline
\end{tabular}




\section{Sample processing and recovery of Eimerian oocysts}

Faecal samples were examined for the presence or absence of Eimerian oocysts by a flotation technique using saturated saline. Oocysts per gram of faeces (OPG) were quantified using a modified McMaster technique (MAFF, 1986). Oocysts in the two chambers of the McMaster slide were counted and the sum number of oocysts in both chambers was multiplied by the dilution factor (100) to obtain an estimation of the number of OPG of each faecal sample. Each faecal sample was examined three times using the same method (Wang et al., 2010; Cavalcante et al., 2012). The results expressed as the mean value of the three independent examinations.

\section{Eimerian species identification}

After examination, positive samples were filtered through sieves covered with folded gauze and centrifuged at $250 \times \mathrm{g}$ for $10 \mathrm{~min}$. Filtered material was placed into Petri dishes with $2.5 \%$ potassium dichromate solution $\left(\mathrm{K}_{2} \mathrm{Cr}_{2} \mathrm{O}_{7}\right)$ for sporulation at laboratory temperature. After sporulation, sporulated oocysts were recovered by centrifugation in saline saturated solution at $250 \times \mathrm{g}$ for $5 \mathrm{~min}$ followed by washing with distilled water. Concentration of sporulated oocysts was performed by centrifugation at $250 \times \mathrm{g}$ for $10 \mathrm{~min}$, stored in potassium dichromate solution at $4 \circ \mathrm{C}$ for subsequent study. The oocysts were identified based on their morphological characteristics (size, shape, colour, form index, presence or absence of micropyle and its cap, presence or absence of residual, polar and stieda bodies) of the oocysts and sporocysts (Pellérdy, 1974; Levine, 1985; Soulsby 1986; Wang et al., 2010; Cavalcante et al., 2012). To ensure that species identification is valid, when possible, at least 50 sporulated oocysts from each species were observed and measured (Wang et al., 2010; Cavalcante et al., 2012). One hundred oocysts were randomly selected and identified to determine the percentages of each Eimeria species present in the fecal samples and then OPG per Eimeria species was counted (Silva et al., 2011). An estimate of intensity of each Eimeria species was achieved by relating their proportions to the McMaster counts (Craig et al., 2007).

\section{Data analysis}

Prevalence was calculated according to Bush et al. (1997). Testing of effects of both individual and interacted factors (host age, sex, season and locality) on species richness of Eimeria species was statistically analyzed using the General Linear Interactive Model (GLIM) after normalization of the data by $\log 10(x+1)$ transformation (Crawley, 1993; Wilson \& Grenfell, 1997; Behnke et al., 1999). Differences in prevalence of Eimeria among different age categories of sheep, as well as among different localities were evaluated using a Chi square test. Comparisons of OPG numbers according to sex and season were tested using Mann-Whitney test (Utest) while according age categories and locality were tested by Kruskal Wallis. Correlations between host age and both prevalence and OPG number were examined by using the non-parametric, Spearman's rank correlation coefficients $\left(r_{s}\right)$. Diversity of Eimeria species was measured using the Shannon-Weiner diversity index. All the statistical tests were performed by using the software packages SPSS 17.0 (USA) and a value of $\mathrm{P}<0.05$ was considered significant.

\section{RESULTS}

Out of 487 faecal samples examined, 227 (46.61\%) were positive for Eimeria oocysts. The species composition of Eimeria consisted of eight species. Eimeria species were E. crandallis (29.8\%), E. bakuensis (27.9\%), E. weybridgensis (23.4\%), 
E. ahsata (12.3\%), E. intricate (9.9\%), E. faurei (7.6\%), E. parva (4.7\%) and E. pallida $(2.9 \%)$. The prevalence of these Eimeria species was shown in Fig. (1). E. crandallis $(29.8 \%)$, E. bakuensis $(27.9 \%)$, and E. weybridgensis $(23.4 \%)$ were the most prevalent Eimeria species. (Fig.1). The abundance and intensity of Eimeria species are showen in Table (2). The most abundant species was E. crandallis.

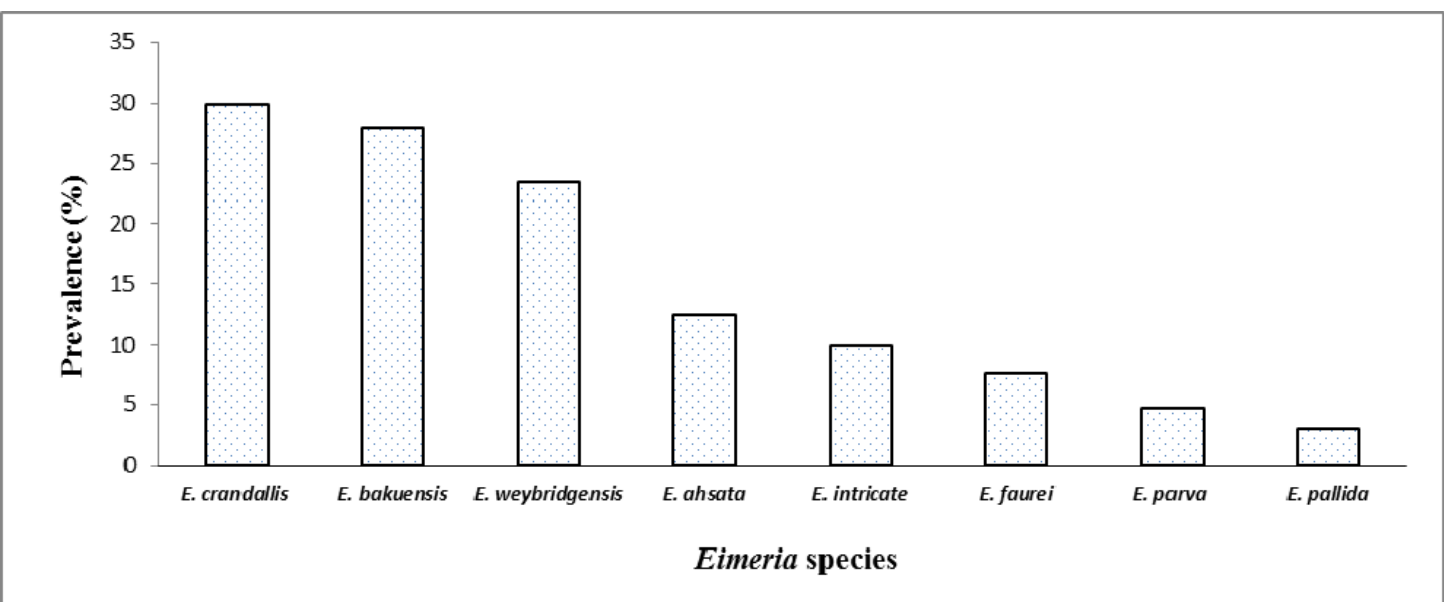

Fig 1: Prevalence of Eimeria species in sheep.

Table 2: Abundance (mean $\pm \mathrm{SE}$ ) and intensity(mean $\pm \mathrm{SE}$ ) of Eimeria species in sheep.

\begin{tabular}{lcc}
\hline Eimeria species & Abundance \pm SE & Intensity \pm SE \\
\hline E. crandallis & $206.55 \pm 39.53(0-1600)$ & $274.78 \pm 20.83(50-1600)$ \\
E. bakuensis & $158.7 \pm 25.36(0-1400)$ & $189.44 \pm 17.41(30-1400)$ \\
E.weybridgensis & $145.77 \pm 21.09(0-2023)$ & $207.59 \pm 24.84(30-2023)$ \\
E. ahsata & $43.11 \pm 9.43(0-1400)$ & $118.66 \pm 15.58(50-1400)$ \\
E. intricate & $29.76 \pm 6.92(0-1000)$ & $100.70 \pm 13.88(20-1000)$ \\
E. faurei & $21.54 \pm 5.96(0-600)$ & $94.62 \pm 11.58(20-600)$ \\
E. parva & $15.18 \pm 5.6(0-800)$ & $70.28 \pm 12.89(20-800)$ \\
E. pallida & $12.68 \pm 3.78(0-650)$ & $50.13 \pm 18.39(20-650)$ \\
\hline
\end{tabular}

The overall mean species richness of Eimeria species harbored per host was $1.27 \pm 0.07$ (S.E.M.). Analysis of these data with GLIM revealed that host age, season and location played a significant role in determining Eimeria species richness and there was interaction between season and location (Table 3). There is a negative correlation between host age and no. of Eimeria species ( $\mathrm{rs}=-0.17, \mathrm{P}<0.001)$. Diversity of Eimeria species was measured using the Shannon-Weiner diversity index. The overall diversity of Eimeria community was 2.381. Diversity in terms of prevalence significantly decreased with age $\left(\mathrm{F}_{2,484}=9.99, P<0.001\right)$ and showed significant differences between season $\left(\mathrm{F}_{1,485}=11.39, P=0.001\right)$ and location $\left(\mathrm{F}_{2,484}=7.23, P=0.001\right)$.

Table 3: Test of interaction (general linear model) between factors affecting species richness of Eimeria in sheep.

\begin{tabular}{ccccccr}
\hline Overall Eimeria species & Factor considered & SS & $\mathbf{d f}$ & $\mathbf{X}^{\mathbf{2}}$ & $\mathbf{F}$ & Sig. \\
\hline season & 12.272 & 1 & 12.272 & 5.337 & .021 \\
Age & 22.986 & 2 & 11.493 & 4.998 & .007 \\
location & 24.200 & 2 & 12.100 & 5.262 & .006 \\
& season * location & 16.261 & 2 & 8.130 & 3.536 & .030 \\
\hline
\end{tabular}


The overall prevalence of Eimeria species in the three localities of Al-Baha area ranged from $35.15 \%$ to $55.48 \%$. Statistically significant difference was found in prevalence $\left(\mathrm{X}^{2}=12.98, d f=2, P=0.002\right)$ and OPG $\left(\mathrm{X}^{2}=14.10, d f=2, P=0.001\right)$ among different localities of Al-Baha area. The highest prevalence $(55.48 \%)$ and OPG (245.82 \pm 37.51$)$ were observed in sheep in Al-Mekhwah locality. The lowest prevalence $(35.15 \%)$ and OPG $(163.56 \pm 25.58)$ were observed in sheep in Al-Baha locality (Table 4).

Table 4: Prevalence and parasite abundance (mean \pm SE) of Eimeriaoocystsin sheep in different localities of Al-Baha area.

\begin{tabular}{lccccc}
\hline Locality & $\begin{array}{c}\text { Examined } \\
\text { number }\end{array}$ & $\begin{array}{c}\text { Infected } \\
\text { number }\end{array}$ & $\begin{array}{c}\text { Prevalence } \\
\mathbf{( \% )}\end{array}$ & $\begin{array}{c}\text { Significance among } \\
\text { location }\end{array}$ & $\begin{array}{c}\text { Mean no. of oocysts per } \\
\text { gram of faeces (range) }\end{array}$ \\
\hline Al-Baha & 165 & 58 & 35.15 & & $163.56 \pm 25.58(0-1900)$ \\
Al-Aqiq & 176 & 88 & 50 & $X^{2}=14.10, d f=2, P=0.001$ & $224.44 \pm 32.59(0-2050)$ \\
Al-Mikhwah & 146 & 81 & 55.48 & & $245.82 \pm 37.51(0-2400)$ \\
\hline
\end{tabular}

The overall prevalence of Eimeria oocysts in male was higher $(48.08 \%)$ than that in female (44.93\%). Also, the OPG number was higher in male $(216.94 \pm 29.82)$ when compared to female $(202.53 \pm 24.96)$. However there were no statistically significant difference in prevalence $\left(\mathrm{X}^{2}=0.48, \mathrm{df}=1, P=0.48\right)$ and OPG $(U=28670.5$; $P=0.55$ ) between male and female (Table 5).

Table 5: Prevalence and abundance (mean \pm SE) of Eimeriaoocystsper host sex of sheep.

\begin{tabular}{cccccc}
\hline Host sex & $\begin{array}{c}\text { Examined } \\
\text { number }\end{array}$ & $\begin{array}{c}\text { Infected } \\
\text { number }\end{array}$ & $\begin{array}{c}\text { Prevalence } \\
\mathbf{( \% )}\end{array}$ & $\begin{array}{c}\text { Significance } \\
\text { between host sex } \\
\text { prevalence }\end{array}$ & $\begin{array}{c}\text { Mean no. of oocysts per } \\
\text { gram of faeces (range) }\end{array}$ \\
\hline Male & 260 & 125 & 48.08 & & $216.94 \pm 29.82(0-2400)$ \\
& 227 & 102 & 44.93 & $X^{2}=0.48, d f=1$, & $202.53 \pm 24.96(0-2050)$ \\
\hline Ovemale & 487 & 227 & 46.61 & & $210.22 \pm 19.59(0-2400)$ \\
\hline
\end{tabular}

The overall prevalence of Eimeria species in different age categories were $58.43 \%, 46.47 \%$, and $33.77 \%$ in $<6$-months old, $6-12$-months old and $>12$-months old respectively. OPG number was higher $(386.45 \pm 43.54)$ in $<6$-months when compared to other age categories (Table 6). Significant difference was found in prevalence $\left(X^{2}=19.28, d f=2, P<0.001\right)$ and OPG number $\left(X^{2}=31.24, d f=2, P<0.001\right)$ among different age categories (Table 6). The overall prevalence, abundance and intensity decreased with increasing host age. Significant negative associations were found between host age and prevalence $\left(r_{s}=-0.20, \mathrm{P}<0.001\right)$, OPG load $\left(r_{s}=-0.28, \mathrm{P}<0.001\right)$ and intensity $\left(r_{\mathrm{s}}=-0.32, \mathrm{P}<0.001\right)$.

Table 6: Prevalence and parasite load(mean \pm SE) of Eimeriaoocysts in different age categories of sheep.

\begin{tabular}{lccccc}
\hline Age categories & $\begin{array}{c}\text { Examined } \\
\text { number }\end{array}$ & $\begin{array}{c}\text { Infected } \\
\text { number }\end{array}$ & $\begin{array}{c}\text { Prevalence } \\
\mathbf{( \% )}\end{array}$ & $\begin{array}{c}\text { Significance among } \\
\text { age categories } \\
\text { prevalence }\end{array}$ & $\begin{array}{c}\text { Mean no. of oocysts per } \\
\text { gram of faeces (range) }\end{array}$ \\
\hline$<$ 6months old & 166 & 97 & 58.43 & $\mathrm{X}^{2}=19.28, d f=2$, & $386.45 \pm 43.54(0-2400)$ \\
6-12 months old & 170 & 79 & 46.47 & $P<0.001$ & $159.25 \pm 20.72(0-1287)$ \\
$\geq \mathbf{1 2}$ months old & 151 & 51 & 33.77 & & $73.88 \pm 12.31(0-832)$ \\
\hline Overall & 487 & 227 & 46.61 & & $210.22 \pm 18.52(0-2400)$ \\
\hline
\end{tabular}

There was seasonal difference in prevalence of Eimeria oocysts in sheep. The prevalence of coccidial oocysts was significantly higher $(54.03 \%)$ in wet season than that in dry season $(38.91 \%)\left(\mathrm{X}^{2}=11.15, d f=1, P=0.001\right)$. OPG numbers were 
significantly higher in wet season $(224.24 \pm 29.23)$ when compared to that in dry season (Table 7; $U=25779, P=0.007$ ).

Table 7: Prevalence and parasite loadof Eimeriaoocysts in different seasons in Al-Baha area, Saudi Arabia

\begin{tabular}{llllll}
\hline Season & $\begin{array}{l}\text { Examined } \\
\text { number }\end{array}$ & $\begin{array}{l}\text { Infected } \\
\text { number }\end{array}$ & $\begin{array}{l}\text { Prevalence } \\
(\%)\end{array}$ & $\begin{array}{l}\text { Significance among age } \\
\text { categories prevalence }\end{array}$ & $\begin{array}{l}\text { Mean no. of oocysts per } \\
\text { gram of faeces (range) }\end{array}$ \\
\hline Dry season & 239 & 93 & 38.91 & & $195.68 \pm 25.24(0-2023)$ \\
Wet season & 248 & 134 & 54.03 & $X^{2}=11.15, d f=1, P=0.001$ & $224.24 \pm 29.23(0-2400)$ \\
\hline
\end{tabular}

Multiple-species infections (simultaneous infections with multiple parasite species in one individual host) of Eimeria species were commonly present in all age categories and declined with host age. $90.74 \%$ of positive sheep carried two to five species, and $78.85 \%$ of positive sheep had two to three species. Infections with 4 and 5 species were less common (11.89\%;) (Table 8). Some Eimeria species consistently co-occurred. Four positive pair-wise associations were found. These were between (i) E. crandallis and E. bakuensis $\left(r_{s}=-0.94, P<0.001\right)$; (ii) E. crandallis and E. ahsata $\left(r_{s}=-0.29, P<0.001\right)$; (iii) E. ahsata and E. bakuensis $\left(r_{s}=-0.28, P<0.001\right)$ and (iv) $E$. crandallis and $E$. weybridgensis $\left(r_{s}=-0.20, P<0.001\right)$. No negative associations were found.

Table 8: Percentage of single andmultiple-species infections of different Eimeria species in sheep in Al-Baha, Saudi Arabia.

\begin{tabular}{lllllll}
\hline $\begin{array}{l}\text { The number of Eimeria species } \\
\text { in examined samples }\end{array}$ & $\mathbf{0}$ & $\mathbf{1}$ & $\mathbf{2}$ & $\mathbf{3}$ & $\mathbf{4}$ & $\mathbf{5}$ \\
\hline $\begin{array}{l}\text { Infected sheep } \\
\text { Percentage (\%) }\end{array}$ & 260 & 21 & 78 & 101 & 20 & 7 \\
\hline
\end{tabular}

\section{DISCUSSION}

Information on the species composition and prevalence of Eimeria spp. is important to implement effective control programs. Previously, elven Eimeria spp. had been identified from sheep in Saudi Arabia (Kasim \& Al-Shawa, 1985; Toulah, 2007). In the present study, the species composition of Eimeria consisted of only eight species namely, E. crandallis, E. bakuensis, E. weybridgensis, E. ahsata, E. intricate, $E$. faurei, E. parva and E. pallida. The recorded species is similar to those recorded by Kasim and Al-Shawa (1985) and Toulah (2007) except E. ninakohlyakimovae, E. granulosa and E. arloingi which were not observed in the present work. In the present investigation, the overall prevalence of Eimeria species infection was $46.61 \%$. This finding is higher than that recorded in Jeddah, Saudi Arabia (Toulah, 2007), Malayer suburb, Iran (Yakhchali \& Rezaei, 2010) which revealed a prevalence of $41 \%$, and $23.32 \%$ in sheep respectively. On contrast, the present recorded prevalence is lower than those reported in the Eastern (93.3\%), Western (90.6\%), Southern (89.8\%), Central $(97.4 \%)$ and Northern $(77.5 \%)$ regions of Saudi Arabia (Kasim \& Al-Shawa, 1985), northeastern China (92.9\%, Wang et al., 2010), Nigeria (80\%, Majaro \& Dipeolu, 2012). These differences in prevalence may be due to various sanitation efforts in the management programs attempted by sheep producers to control coccidiosis or due to differences in ecological condition. E. crandallis (29.8 $\%)$, E. bakuensis (27.9\%), and E. weybridgensis (23.4\%) were the most prevalent Eimeria species. Similarly, Kasim and Al-Shawa (1985) and Craig et al (2007) found that $E$. bakuensis and E. weybridgensis were the most common species in sheep (Ovis aries L.) in Saudi Arabia and UK. 
Statistically significant difference was found in prevalence and OPG load among different localities of Al-Baha area. The highest prevalence and OPG were observed in Al-Mekhwah locality. Kasim and Al-Shawa (1985) found variation in prevalence of infection in study sites and correlate it to difference in rainfall and humidity. The difference in prevalence and abundance of infection per location is probably due to difference in ecological parameters (such as rainfall, humidity and temperature).

Although, the overall prevalence and OPG of Eimeria oocysts in male were higher than that in female, there were no statistically significant differences. Similar finding was found by Maingi \& Munyua (1994) and Yakhchali, \& Rezaei, (2010). On the hand, Craig et al. (2007) found that males have significantly higher burdens of protozoan than females. They correlate this difference due to difference in reproductive fitness costs.

The prevalence as well as intensity and diversity of mixed Eimeria spp. declined with host age. All species were more prevalent in juveniles and all species were more intense in juveniles. This general juvenile bias in infection of Eimeria spp. is well documented in domestic sheep throughout the world (Maingi \& Munyua, 1994; Arslan et al., 1999). Acquired immunity has been shown to cause a decrease in infection of various Eimeria species with host age (Yun et al., 2000). The prevalence and OPG of Eimeria oocysts in lower age category were significantly higher than that in adult sheep. These findings are consistent with previous observations (Maingi \& Munyua, 1994; Arslan et al., 1999; Wang et al., 2010). This has been attributed to lower resistance or less immunity to Eimeria species in young animals compared to the older animals (Gregory et al., 1980; Maingi \& Munyua, 1994). Although acquired resistance is likely to contribute to the negative association of infection with host age, Ortega-Mora and Wright (1994) demonstrated an independent age-related resistance to infection in which a significant extension of the pre-patent period and decrease in intensity.

The prevalence and OPG of Eimeria species in wet season were significantly higher than that in dry season. Similarly, Majaro and Dipeolu (1981), El-Bahy et al. (2008) and Bakunzi et al. (2010) found higher Eimeria oocyst counts during the hot, rainy season than those during the cold, dry season. El-Bahy et al. (2008) reported that Coccidia sp. are abundant during April to June and their incubation period is about 1-2 week, so new infection could be occur in the same period as end of March till end of June. On the contrast, other researchers observed that there was no significant difference in OPG during seasons (Maingi \& Munyua, 1994).

The present results demonstrated that multiple-species infections with two or three Eimeria species were more commonly seen than infection with a single Eimeria species. This finding is consistent with the findings of other researchers (Kasim \& AlShawa, 1985; Craig et al., 2007; Wang et al., 2010; Majaro \& Dipeolu, 1981). Four positive pair-wise associations were found. These were between (i) E. crandallis and E. bakuensis; (ii) E. crandallis and E. ahsata; (iii) E. ahsata and E. bakuensis and (iv) $E$. crandallis and E. weybridgensis. This finding is consistent with the finding of Craig et al. (2007). Craig et al. (2007) explained the positive pair-wise correlations between Eimeria species for one of two reasons. The first one is the overdispersion of parasites in natural populations, that is most individuals harbour few parasites and a few harbour many. They relate the aggregation may be due to variation in the exposure or susceptibility to infection within the host population. Various factors influence susceptibility in the sheep such as host age, sex, previous exposure to infection and nutritional status. Variation in any of these factors, causing aggregation 
both within and across parasite taxa, could therefore explain the positive associations observed between protozoan species. The second, or alternatively, to this main effect, it is possible that concurrent parasite infection exerts a synergistic effect. Although not easy to detect (Behnke et al., 2005) such interactions have recently been documented for protozoa (Bajer et al., 2002) in wild mammal populations. That is, infection with one species enhances proliferation of another species. For instance, Catchpole et al. (1976) found that pure inoculations of four species of Eimeria in lambs produced shorter patent infections than when all four species were administered at once. The immunogenicity of the different parasite species and the extent to which hosts develop cross-immunity will play a role in this phenomenon. The positive pairwise interactions that found in this study may be result from synergistic effect of concurrent parasite infection.

In conclusion, the prevalence and parasite load are affected by host age and season. We need further research to study the interaction between multiple-species infections in natural host-parasite systems. These results also provide relevant "baseline" data for assessing the effectiveness of future control strategies against coccidiosis in sheep.

\section{ACKNOWLEDGMENTS}

We are grateful to Al-Baha University for financing this project (Grant No. 4/1433). The authors would like to thank the workers of the farms for their assistance in the collection of specimen and their help. We also thank the farms owners who allowed us to use animals for the study.

\section{REFERENCES}

Arslan, M.O., Umur, S. and Kara, M. (1999). The prevalence of coccidian species in sheep in Kars province of Turkey. Trop. Anim. Health Prod., 31: 161-165.

Bajer, A., Bednarska, M., Pawelczyk, A., Behnke, J.M., Gilbert, F.S. and Sinski, E (2002). Prevalence and abundance of Cryptosporidium parvum and Giardia spp. in wild rural rodents from the Mazury lake district region of Poland. Parasitology, 125: 21-34.

Bakunzi, F.R., Thwane, S.N., Motsei, L.E. and Dzoma, B.M. (2010). Diversity and seasonal occurrence of Eimeria species in a mixed flock of communally reared sheep and goats in Mafikeng in the North West Province, South Africa. J. S. Afr. Vet. Assoc., 81(3): 148-1450.

Behnke, J.M., Lewis, J.W., Mohd Zain, S.N. and Gilbert, F.S. (1999). Helminth infections in Apodemus sylvaticus in southern England: interactive effects of host age, sex and year on the prevalence and abundance of infections. J. Helminthol., 73: 31-44.

Behnke, J.M., Gilbert, F.S., Abu-Madi, M.A. and Lewis, J.W. (2005). Do helminth parasites of wood mice interact? J Anim. Ecol., 74: 982-993.

Brooker, S. and Clements, A.C. (2009). Spatial heterogeneity of parasite coinfection: Determinants and geostatistical prediction at regional scales. Int. J. Parasitol., 39(5):591-597.

Bush, A.O., Lafferty, K.D., Lotz, J.M. and Shostak, A.W. (1997). Parasitology meets ecology on its own terms: Margolis et al., revisited. J. Parasitol., 83: 575-583.

Catchpole, J., Norton, C.C. and Joyner, L.P. (1976). Experiments with defined multispecific coccidial infections in lambs. Parasitology, 72: 137-147. 
Cavalcante, A. C.; Teixeira, M.; Monteiro, J. P. and Lopes, C. W. (2012). Eimeria species in dairy goats in Brazil. Vet. Parasitol., 183(3-4): 356-358.

Craig, B.H., Pilkington, J.G., Kruuk, L.E. and Pemberton, J.M. (2007). Epidemiology of parasitic protozoan infections in Soay sheep (Ovis aries L.) on St Kilda. Parasitology, 134 (Pt 1): 9-21.

Crawley, M.T. (1993). GLIM for Ecologists. Blackwell Scientific Press, Oxford.

El-Bahy, M.M., Omer, O.H. and Al-Sadrani, A.A, (2008). Temperature difference and parasite infection at Qassim region, Saudi Arabia. Res. J. Parasitol., 3: 114-122.

Foreyt, W.J. (1990). Coccidiosis and cryptosporidiosis in sheep and goats. Vet. Clin. North. Am. Food. Anim. Pract., 6 (3): 655-670.

Graham, A.L. (2008). Ecological rules governing helminth-microparasite coinfection. Proc Nat. Acad. Sci. U. S. A., 105: 566-570.

Gregory, M.W., Joyner, L.P., Catchpole, J. and Norton, C.C. (1980). Ovine coccidiosis in England and Wales 1978-1979. Vet. Rec., 106: 461-462.

Griffiths, E.C., Pedersen, A.B., Fenton, A. and Petchey, O.L. (2011). The nature and consequences of coninfection in humans. J. Infect., 63: 200-206.

Ibrahim, M.M., Al Ghamdi, M.A. and Al Gahmdi, M.S, (2008). Helminths community of veterinary importance of livestock in relation to some ecological and biological factors. Turkiye Parazitol. Derg., 32 (1): 42-47.

Kasim, A.A. and Al-Shawa, Y.R. (1985). Coccidia in sheep (Ovis aries) in Saudi Arabia. J. Coll. Sci. King. Saud. Univ., 16: 221-226.

Lello. J., Boag, B., Fenton, A., Stevenson, I.R. and Hudson, P.J. (2004). Competition and mutualism among the gut helminths of a mammalian host. Nature, London 428: 840-844.

Levine, N.D. (1985). Veterinary Protozoology. Iowa State University Press, Ames, IA, pp. 150-202.

Maingi, N. and Munyua, W.K. (1994). The prevalence and intensity of infection with Eimeria species in sheep in Nyandarua district of Kenya. Vet. Res. Commun., 18: $19-25$.

Majaro, O. M. and Dipeolu, O. O. (1981). The seasonal incidence of coccidia infections in trade cattle, sheep, and goats in Nigeria. Vet. Q. $3(2): 85-90$.

Ministry of Agriculture, Fisheries and Food, UK (MAFF). (1986). Manual of veterinary parasitological laboratory techniques. Reference book 418.Her Majesty's Stationery Office, London.

Ortega-Mora, L.M. and Wright, S.E. (1994). Age-related resistance in ovine cryptosporidiosis: patterns of infection and humoral immune response. Infect. Immun., 62: 5003-5009.

Pellérdy, L.P. (1974). Coccidia and Coccidiosis, 2nd ed. Paul Parey, Berlin,pp. 720: 794-959

Platzer B, Prosl H, Cieslicki M, Joachim A (2005) Epidemiology of Eimeria infections in an Austrian milking sheep flock and control with diclazuril. Vet. Parasitol., 129: 1-9.

Pullan, R. and Brooker, S. (2008). The health impact of polyparasitism in humans: are we under-estimating the burden of parasitic diseases? Parasitology, 135: 783-794.

Raso, G., Vounatsou, P., McManus, D.P. and Utzinger, J. (2007). Bayesian risk maps for Schistosoma mansoni and hookworm mono-infections in a setting where both parasites co-exist. Geospat. Health, 2: 85-96. 
Silva, R.M., Facury-Filho, E.J., Souza, M.F. and Ribeiro, M.F. (2011). Natural infection by Eimeria spp. in a cohort of lambs raised extensively in Northeast Brazil. Rev Bras Parasitol. Vet., 20(2):134-139.

Soulsby, E.J.L. (1986). Helminths, Arthropods and Protozoa of Domesticated Animals, 7th ed. Balliere, London, UK, pp. 599-625.

Toulah, H.F. (2007). Prevalence and comparative morphological study of four Eimeria spp. of sheep in Jeddah area, Saudi Arabia. J. Biol. Sci., 7 (2):413416.

Viney, M. E., Graham, A. L. (2013). Patterns and processes in parasite co-infection. Adv. Parasitol., 82: 321-369.

Wang, C.R., Xiao, J.Y., Chen, A.H., Chen, J., Wang, Y., Gao, J.F. and Zhu, X.Q. (2010). Prevalence of coccidial infection in sheep and goats in northeastern China. Vet. Parasitol., 174: 213-217.

Wilson, K. and Grenfell, B.T. (1997). Generalized linear modelling for parasitologists. Parasitol. Today, 13: 33-38.

Yakhchali, M. and Rezaei, A. (2010). The prevalence and intensity of Eimeria spp. infection in sheep of Malayer suburb, Iran. Archives of Razi Institute, 65 (1): 27-32.

Yun, C.H., Lillehoj, H.S. and Lillehoj, E.P. (2000). Intestinal immune response to coccidiosis. Dev. Comp. Immunol., 24: 303-324.

\section{ARABIC SUMMARY}

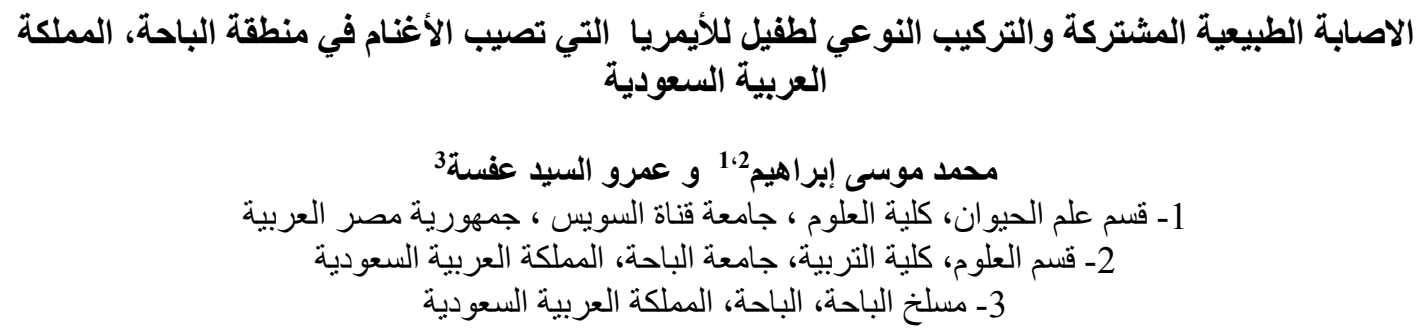

يهدف هذا العمل إلى 1) تعريف أنواع الأيمريا التي تصيب الأغنام، 2) فحص العوامل التي من المحتمل أن تؤثر

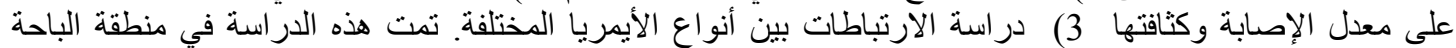

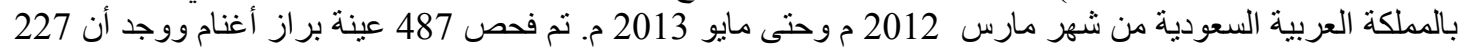

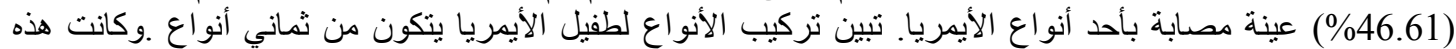

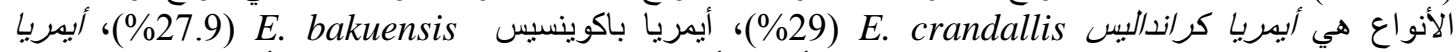

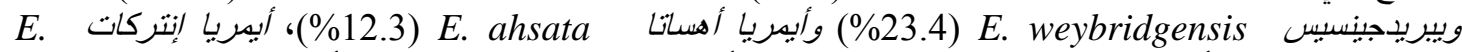

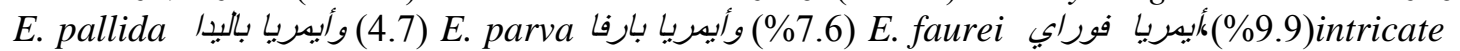

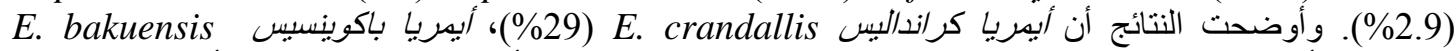

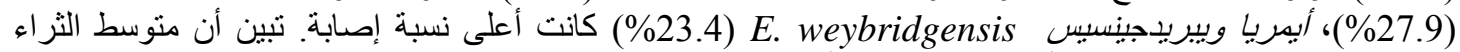

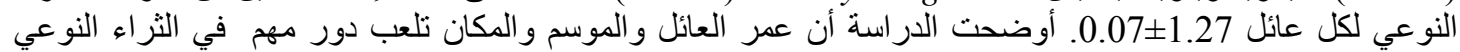

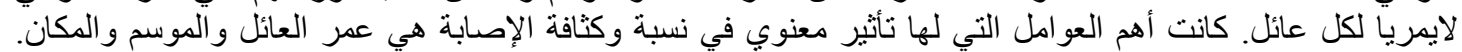

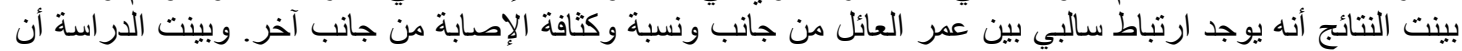

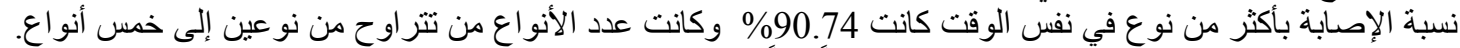

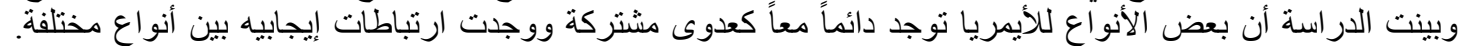

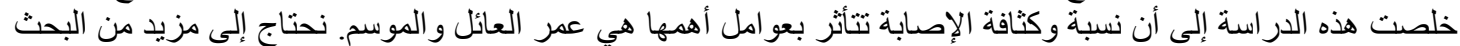
لدر اسة التفاعل بين الإصابة بأكثر من نوع من أنو اع الأيمريا في حالة الإصـابة في الإني نظام الإصابة الطبيعية. 